\title{
Satellite gravimetry for the Fernando de Noronha Chain, Northeast Brazil, and its bearing on the volcanic seamount structure
}

Gravimetria de satellite para a Cadeia Fernando de Noronha, Região Nordeste do Brasil, e sua relação com a estrutura de montes submarinos vulcânicos.

Akihisa Motoki ${ }^{1}$; Kenji Freire Motoki ${ }^{2}$

1) Departamento de Mineralogia e Petrologia Ígnea, Universidade do Estado do Rio de Janeiro rochasornamentais@yahoo.com.br; 2) Departamento de Geologia, Universidade Federal Fluminense

Copyright 2012, SBGf - Sociedade Brasileira de Geofísica

Este texto foi preparado para a apresentação no V Simpósio Brasileiro de Geofísica, Salvador, 27 a 29 de novembro de 2012. Seu conteúdo foi revisado pelo Comitê Técnico do V SimBGf, mas não necessariamente representa a opinião da SBGf ou de seus associados. É proibida a reprodução total ou parcial deste material para propósitos comerciais sem prévia autorização da SBGt.

\section{Abstract}

The authors present the gravimetric and geomorphologic studies for the Fernando de Noronha Chain, western Equatorial Atlantic Ocean, based on the satellite database TOPEX ver. 14.1, and its bearing on the volcanic seamount structure. The volcanic seamounts are generally of $30 \mathrm{~km}$ in base diameter, $10 \mathrm{~km}$ of flat-top diameter, and 3000 to $4000 \mathrm{~m}$ of relative height. The base diameters and the flat-top diameters show a positive correlation, indicating that the volcanic edifices are voluminous and their top was originally much higher than sea level. The large volcanic edifices tend to have steep slope, of about $25^{\circ}$, and are considered to be constituted by lava flows. The small ones have gentle slope of about $7^{\circ}$ and are estimated to be composed of unconsolidated pyroclastic deposits. The southwest foothill of the Sirius Bank and the Guará Bank is covered by thick deposits and they are significantly older than the sediments originated form the continental slope. The flat-top planes of the seamounts are constantly about 50 to $100 \mathrm{~m}$ deep and the basement subsidence of the volcano is not observed. The volcanic seamounts show the Bouguer anomaly about $100 \mathrm{mGal}$ lower than the adjacent abyssal plane, indicating that they are composed of the materials less dense than the oceanic crust, such as lava flows and pyroclastic deposits. The large volcanoes have local maximum Bouguer anomaly at the centre, about $80 \mathrm{mGal}$ higher than the border, showing a ring-like structure. It suggests possible presence gabbroic intrusion at the base of the volcanic edifices. The E-W trend of the Fernando de Noronha Chain is widely different from the NW-word absolute motion vector of the South America Plate. Therefore, the Fernando de Noronha Chain is not considered to be a hot-spot track.

\section{Resumo}

Os autores apresentam os estudos gravimétricos e geomorfológicos para a Cadeia Fernando de Noronha, região ocidental do Oceano Atlântico Equatorial, com base no banco de dados de satélites TOPEX ver. 14.1, e sua indicação sobre a estrutura dos montes submarinos vulcânicos. Os montes submarinos vulcânicos são geralmente de $30 \mathrm{~km}$ de diâmetro da base, $10 \mathrm{~km}$ de diâmetro do topo achatado e 3000 a 4000 m de altura relativa. Os diâmetros da base e do topo mostram uma correlação positiva, indicando que os edifícios vulcânicos são volumosos e o topo desses foi originalmente muito mais alto do que o nível do mar. Os edifícios vulcânicos grandes tendem a possuir o talude de alta declividade, de aproximadamente de $25^{\circ}$, e são considerados como constituídos por fluxos de lava. Os pequenos têm o talude de baixa declividade, em torno de $7^{\circ}$, e são estimados como compostos de depósitos piroclásticos. O sopé do Banco Sirius e do Banco Guabá é coberto por depósitos espessos, sendo que, esses são significativamente mais antigos do que os sedimentos originados do talude continental. Os planos do topo achatado dos montes submarinos possuem profundidade constante de 50 a 100 m e, não se observa a subsidência da base dos vulcões. Os montes submarinos vulcânicos apresentam a anomalia Bouguer em torno de $100 \mathrm{mGal}$ mais baixa do que da planície abissal adjacente, indicando que, esses são constituídos por materiais menos densos do que a crosta oceânica, tais como fluxos de lava e depósitos piroclásticos. Os vulcões grandes possuem alta anomalia Bouguer no centro, cerca de 80 mGal maior do que da borda, apresentando uma estrutura anelar. Esta observação sugere possível existência de intrusão gabróica na base do edifício vulcânico. A orientação E-W da Cadeia Fernando de Noronha é muito diferente do vetor do movimento absoluto da Placa Sul-Americana, que é direcionada ao noroeste, portanto geotectonicamente não é considerado como uma cadeia de hot-spot.

\section{Introduction}

The Fernando de Noronha Chain (Cadeia Fernando de Noronha) is a submarine volcanic sequence with $\mathrm{E}-\mathrm{W}$ trend along the latitude $4^{\circ} \mathrm{S}$ in the western margin of the Equatorial Atlantic Ocean. The seamounts are distributed in the area about $490 \mathrm{~km}$ long and $110 \mathrm{~km}$ wide (Fig. 1). The highest elevations constitute the Fernando de Noronha Island (2) and the Rocas Atoll (6). The volcanic edifice of the Fernando de Noronha Island is $4400 \mathrm{~m}$ in relative height, being the third highest Brazilian volcano.

This island is the only locality where the constituent rocks are exposed. It is constituted mainly by strongly silica-undersaturated alkaline basic to ultrabasic rocks, such as alkaline basalt, basanite and nephelinite, which are intruded by phonolite plugs and small monzonite body (Almeida, 1955). They were studied in geochronology (e.g. Rivalenti et al., 2007) and isotopic geology (e.g. Gerlach et al., 1987). The datings (Cordani, 1970; Buikin et al., 2010) indicate that the magmatism took place at 
about 12 Ma. However, the gravimetric, geomorphologic, and geotectonic studies are scarce.

In recent years, the techniques of satellite gravimetry and predicted bathymetry are in remarkable improvement.
The authors have performed the gravimetric analyses for the Fernando de Noronha Chain using the TOPEX ver. 14.1 satellite data. This paper presents the results and discusses its geotectonic genesis.

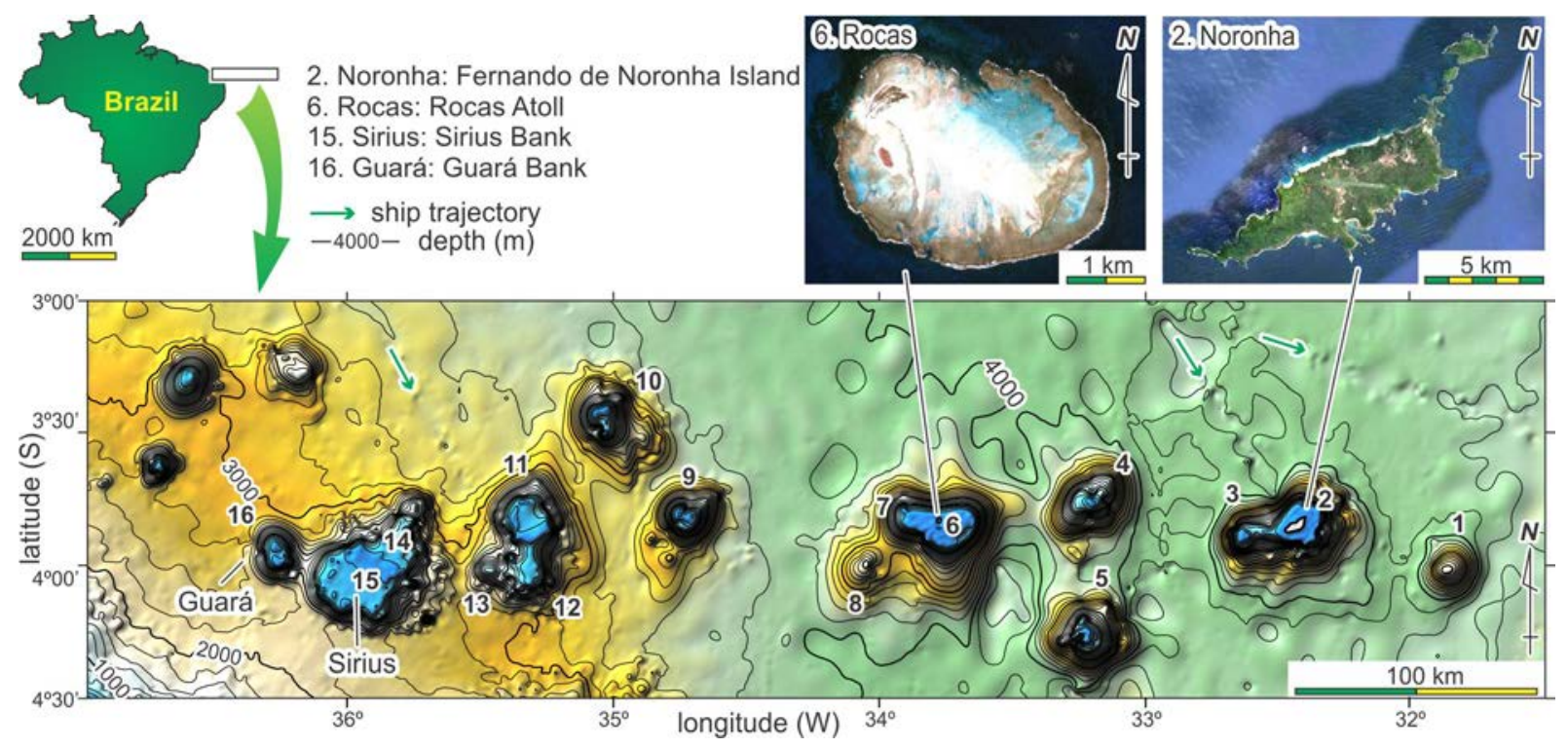

Fig. 1. Predicted bathymetry map for the Fernando de Noronha Chain, Atlantic Ocean of the Northeast Brazil, according to the TOPEX ver. 14.1 database. The satellite images of the Fernando de Noronha Island are originated from Google Earth ${ }^{\mathrm{TM}}$.

\section{Research methods}

The authors have adopted the free-air anomaly and predicted bathymetry of the TOPEX ver. 14.1. They were elaborated based on the technique of Smith \& Sandwell (1997) and are in distribution from the UCSD-SIO. This version has $1.85 \mathrm{~km}$ of resolution and it should be at the theoretical limit of the gravimetry.

The free-air data have been submitted to the Bouguer reduction correction based on the water blade thickness of the predicted bathymetry, which has been performed with the help of original software Schwelt ver. 1.0 build 28 , adopting continental crust density of $2.65 \mathrm{~g} / \mathrm{cm}$, sea water density of $1.01 \mathrm{~g} / \mathrm{cm}$, and gravity constant of $6.67259 \times 10^{-11} \mathrm{~m}^{3} / \mathrm{s}^{2} \mathrm{~kg}$. The gravimetric maps have been elaborated by Excel ${ }^{\mathrm{TM}}$, Surfer ${ }^{\mathrm{TM}}$, and CorelDraw ${ }^{\mathrm{TM}}$.

\section{Volcanic seamounts}

The Fernando de Noronha Chain is constituted by 16 large volcanic edifices. They are almost circular, with general size of $30 \mathrm{~km}$ in base diameter, $10 \mathrm{~km}$ in the flattop diameter, and 3000 to $4000 \mathrm{~m}$ in relative height. The interval between them is about $30 \mathrm{~km}$.

The flat-top planes are about 50 to $100 \mathrm{~m}$ below sea level forming guyots. Their depth is constant and no basement subsidence is observed. The seamounts have a positive correlation between the base diameter and the flat-top diameter (Fig. 2A), suggesting that the volcanic edifices are highly voluminous and their tops were originally higher than sea level.
A. Base diameter vs. flat-top diameter

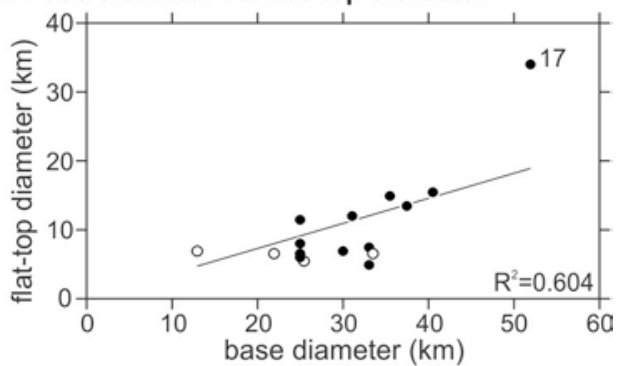

B. Slope declivity vs. height

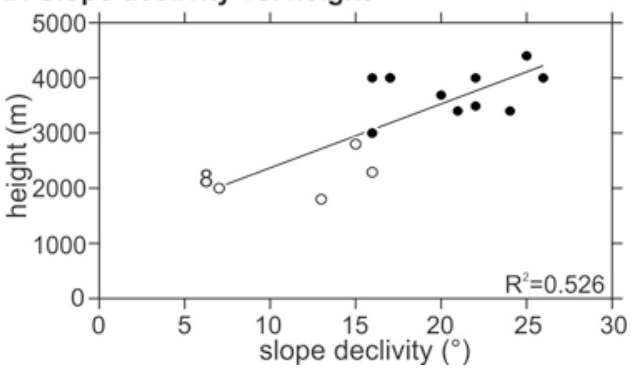

Fig. 2. Diagrams for the comparison of morphologic parameters of the volcanic seamounts of the Fernando de Noronha Chain: A) Base diameter vs. flat-top diameter; B) Slope declivity vs. height.

The slope declivity and volcano height also show positive correlation (Fig. 2B). The large volcanic edifices have steep slope of about $25^{\circ}$, and low ones, gentle slope 
of $7^{\circ}$. This highly contrasted slope angles could be due to the difference of constituent rock bodies, that is, lava flows or pyroclastic deposits.

The Fernando de Noronha Island is made up of two volcanic edifices, that is, Fernando de Noronha Volcano (2) and the FN-3238-0353 Seamount (3). At the southwest and northeast slops of the Fernando de
Noronha Volcano, wide and deep landslide valleys are observed (Fig. 3). Especially, the southwest valley is large, $5 \mathrm{~km}$ wide and at least $1000 \mathrm{~m}$ deep. The Fernando de Noronha is a large shield volcano of $40.5 \mathrm{~km}$ in the base diameter, $15.5 \mathrm{~km}$ in the flat-top diameter, and 4400 $\mathrm{m}$ in relative height.

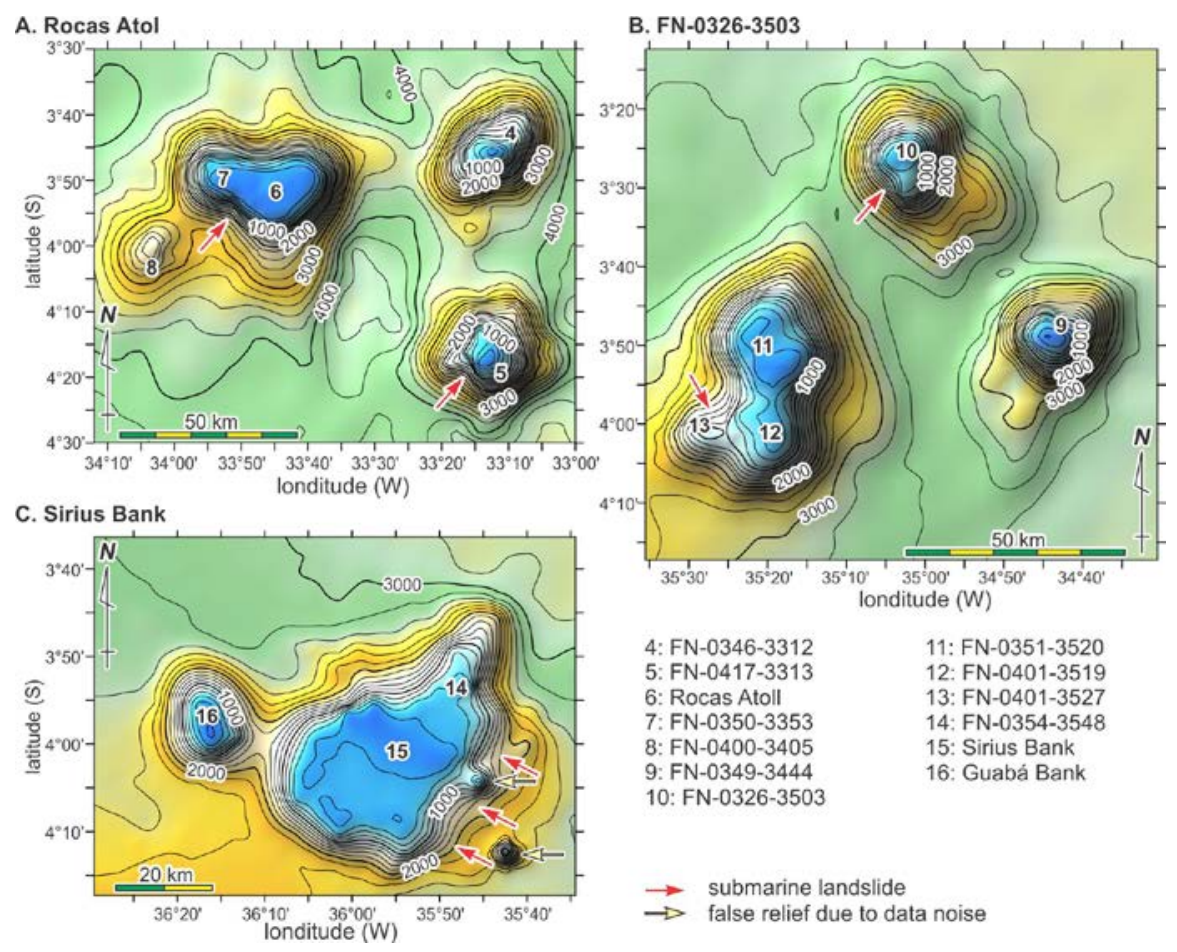

Fig. 3. Detailed predicted bathymetry maps for the areas of: A) Rocas Atoll; B) FN-0326-3503 Seamount; C) Sirius Bank.

The Sirius Bank (15) is the widest volcanic edifice of the Fernando de Noronha Chain, of $52 \mathrm{~km}$ in the base diameter, $34 \mathrm{~km}$ in the flat-top diameter, and $3000 \mathrm{~m}$ in relative height. The shallow flat-top plane very extensive, forming an immense bank. The Seamount FN-0354-3548 (14) and the Guará Bank (16) are smaller volcanic seamounts constituting guyots.

The Sirius Bank (15) and the Guará Bank (16) are situated exceptionally on the foothill of the continental elevation. If they are relatively old volcanoes, thick sedimentary deposits originated from the continental side would burry the volcano foothills. The level difference between the northeast foothill and southwest one of the seamounts, $1300 \mathrm{~m}$, is significantly larger than the regional ones, $600 \mathrm{~m}$ (Fig. 4). Therefore, the continental side foothill should be covered by the sedimentary deposits with minimum thickness of $500 \mathrm{~m}$ and these volcanoes are significantly older than the deposits.

\section{Gravimetric anomalies}

The Fig. 5 shows gravimetric maps of free-air and simple Bouguer anomalies. The free-air map shows a close relation between gravimetric anomaly and depth. On the continental shelf the free-air anomaly is about 40 $\mathrm{mGal}$ and on the abyssal plane, about $-20 \mathrm{mGal}$. The free-air anomaly op of the seamounts is of about 200 $\mathrm{mGal}$ higher than that of the abyssal plane. Although the flat-top of the seamounts is close to sea level, being almost at the same depth, the free-air anomaly is not homogeneous. The Fernando de Noronha Island (2) and the Rocas Atoll (6) have high free-air anomaly, respectively 240 and $230 \mathrm{mGal}$. On the other hand, the seamounts FN-0346-3312 (4), FN-0417-3313 (5), FN0349-3444 (9), FN-0326-3503 (10) are of lower anomaly, respectively $150,170,150$, and $170 \mathrm{mGal}$. Large seamounts, as Sirius Bank (15), Guará Bank (16), and Canopus Bank, also have lower anomaly, respectively 180,140 , and $160 \mathrm{mGal}$.

Between the continental slope and the Sirius Bank (15) there is a low free-air zone. This area occurs on the continental elevation and the low gravity can be attributed to the sedimentary deposits originated from the continental slope. According to the relative anomaly of 50 $\mathrm{mGal}$, the thickness is estimated to be $2500 \mathrm{~m}$. 


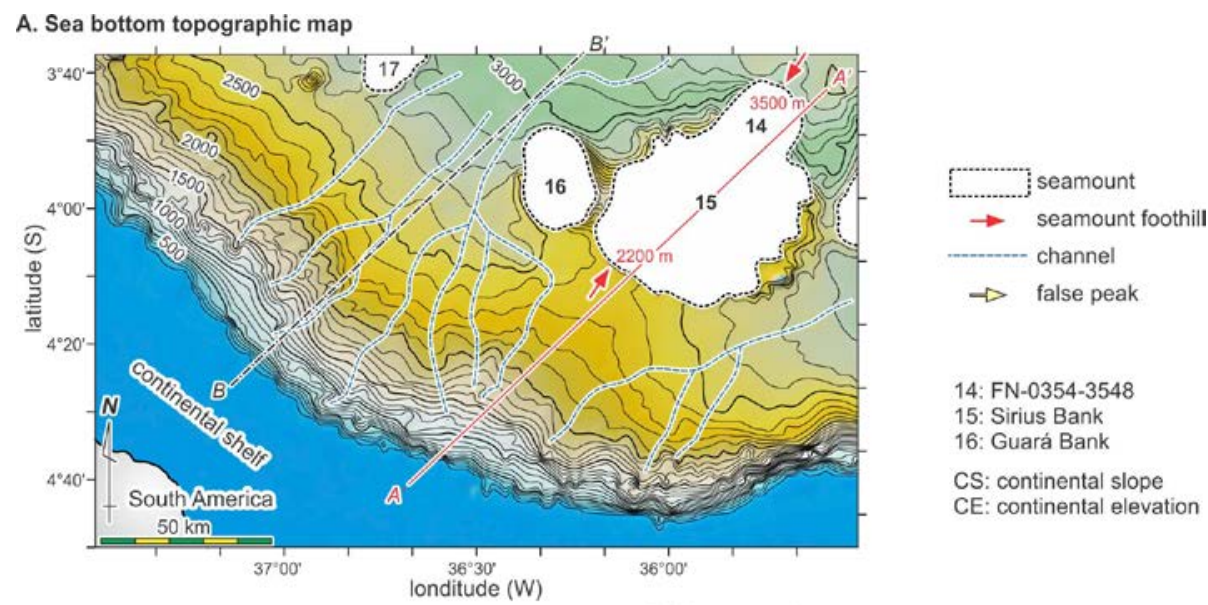

B. Oblique view of the bathymetry
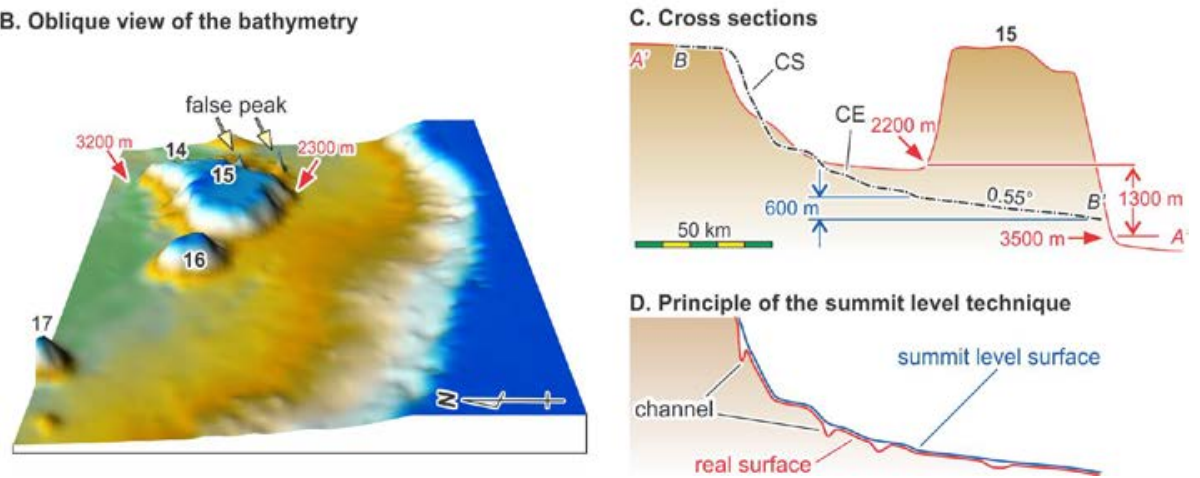

Fig. 4 Submarine morphology around the Sirius Bank (15): A) Ocean bottom topographic map; B) Oblique view; C) Cross sections of the summit level surface based on the mesh interval of $9.4 \mathrm{~km}$; D) Principle of the summit level technique.
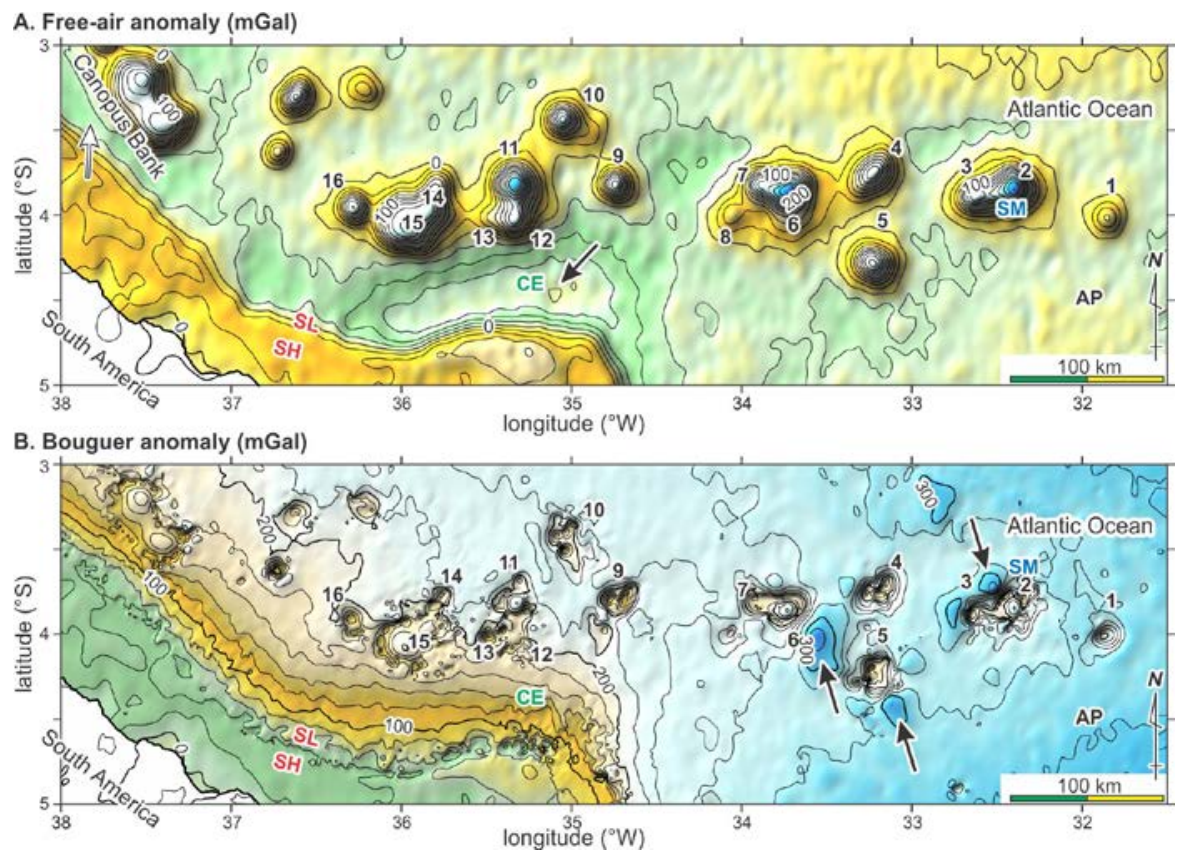

Fig. 5 Gravimetric anomaly maps for the Fernando de Noronha Chain Area based on the satellite data of the TOPEX ver. 14.1: A) Free-are anomaly. B) Simple Bouguer anomaly. 

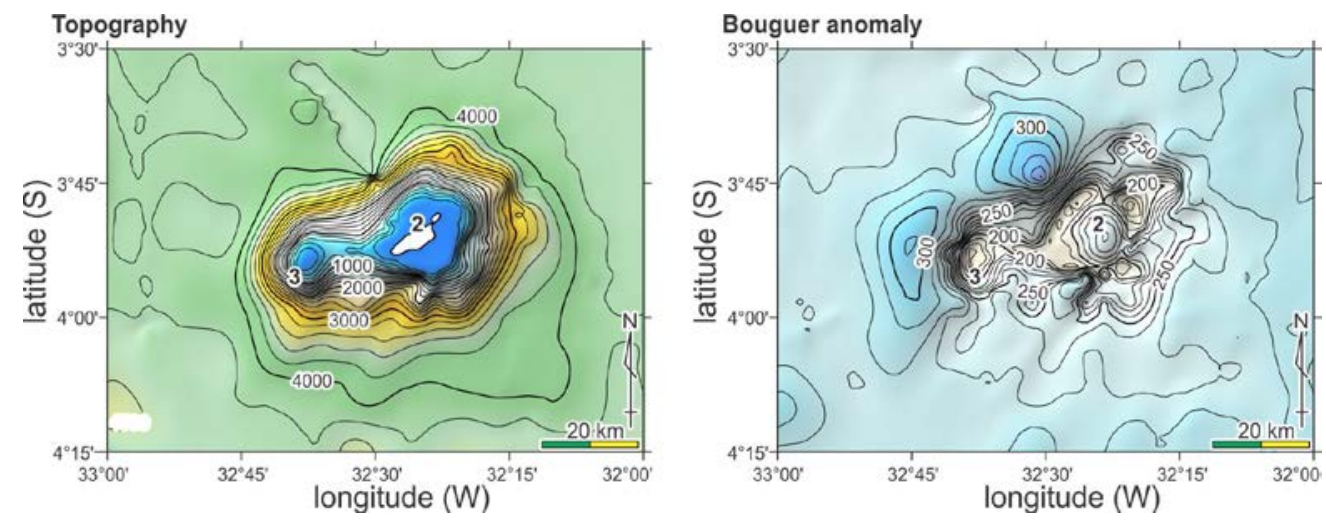

Fig. 6. Predicted bathymetry map (A) and simple Bouguer anomaly map (B) for the volcano of the Fernando de Noronha Island (2) and the Seamount FN-3238-0353 (3).

The Bouguer anomaly map shows low anomaly in the continental shelf, about $20 \mathrm{mGal}$, and high anomaly in the abyssal plane, about $280 \mathrm{mGal}$. The volcanic seamounts show Bouguer anomaly about $100 \mathrm{mGal}$ lower than the adjacent abyssal plane. Some large volcanoes have Bouguer anomaly at the centre 60 to $80 \mathrm{mGal}$ higher than the border (Fig. 6). This phenomenon is possibly due to the gabbroic intrusion in the base level of the large volcanic edifices. Close to the Fernando de Noronha Island (2), the Seamount FN-0417-3313 (5), and the Rocas Atoll (7), there are high gravity areas (Fig. 5B, black arrows).

The Fig. 7 presents the relationship between gravimetric anomalies and depth. The geomorphologic and geologic units of the target area are plotted on the specific areas of these diagrams. Close to the sea level, continental shelf (Figure 11, $\mathrm{SH}$ ) and flat-top of the seamounts (GY) constitute two distinct groups of the shallow zone with the gravimetric anomalies respectively of 0 to $40 \mathrm{mGal}$ and 120 to $240 \mathrm{mGal}$.

The seamounts (SM) show positive correlation between free-air anomaly and altitude and high-angle negative correlation between Bouguer anomaly and altitude. These observations suggest that the volcanic edifices are sustained not only by rigid oceanic crust but also by isostasy. The data for the abyssal plane presents a negative correlation between the Bouguer anomaly and depth, but the free-air anomaly is constantly about -20 $\mathrm{mGal}$. This fact indicates that the abyssal plane almost is in isostatic equilibrium. The gravimetric anomalies of the continental elevation are about $50 \mathrm{mGal}$ lower than that of the abyssal plane of the same depth. The fact suggests that the maximum thickness of the sedimentary cover is about $2500 \mathrm{~m}$.

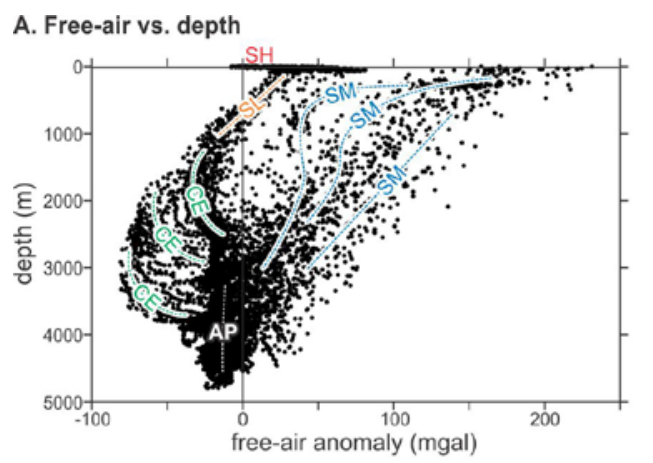

B. Bouguer vs. depth
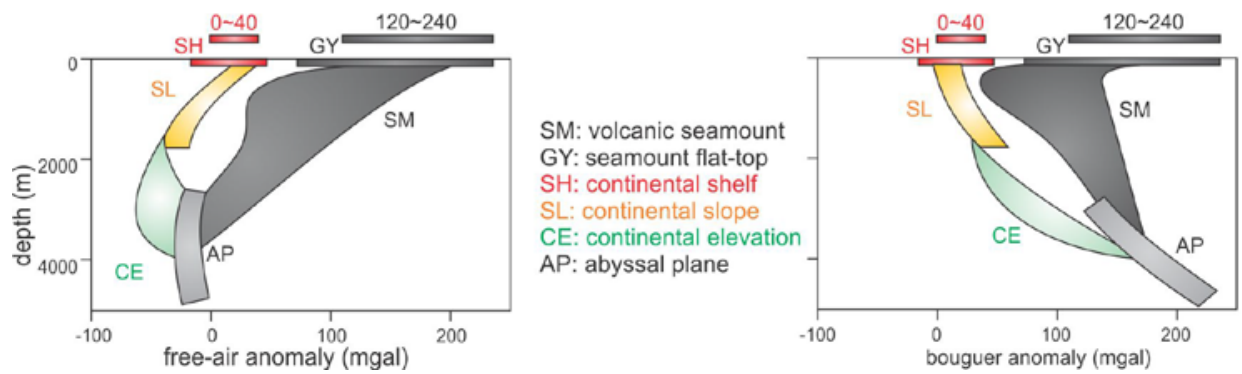

Fig. 7. Relation between the gravimetric anomalies and depth for the Fernando de Noronha Chain and adjacent area, western Equatorial Atlantic Ocean: A) Free-air anomaly; B) Bouguer anomaly. 


\section{Geotectonic genesis of the magmatism}

The previous papers proposed two different ideas for the genesis of the Fernando de Noronha Chain volcanism: 1) Magmatism along an abyssal fracture zone (e.g. Almeida, 1955); 2) Hot-spot track (e.g. Silveira \& Stutzmann, 2002). Recently, an alternative idea of hydrated mantle melting has been proposed (e.g. Skolotnev et al., 2010; Motoki et al., 2012).

The predicted bathymetric map (Fig. 1) shows that the Fernando de Noronha Chain is not linked directly to any systems of active transform faults and abyssal fracture zones of the Atlantic Ocean. In addition, the volcanic chain and the abyssal fracture zones are not exactly parallel, but direction discrepancy of $10^{\circ}$. Transform faults and abyssal fracture zones are cold mantle zones, which is unfavourable for magma generation in normal condition.

The hot-spot track direction is according to the absolute motion of the plate, that is, the plate movement relative to the world-wide hot-spots. If one direction of the magmatic chains is hot-spot track, anther direction is of different geotectonic genesis. O'Connor \& Roex (1992) indicate that the absolute motion vector of the South America Plate is about $\mathrm{N} 35^{\circ} \mathrm{W}$ and the NE-SW trend alignments are of hot-spot tracks. Therefore, the Fernando de Noronha Chain is not considered to be a hot-spot track. For the same reason, the Vitória-Trindade Chain also is not a hot-spot track.

In this moment, no conventional geotectonic model can justify the E-W trend magmatism of the Fernando de Noronha Chain. An alternative idea is horizontal penetration of asthenosphere-origin hot mantle along the abyssal fracture zone from the west to the east (Skolotnev et al., 2010). The abyssal fracture zone should be hydrated due to the serpentinization and the water can help the melting of the hot mantle (Motoki et al., 2012).

\section{Acknowledgement}

The present work has been executed with the help of the high-duty equipments of the informatics that were obtained by financial support of the FAPERJ. The authors are grateful to the institution.

\section{Reference}

Almeida, F.F.M. 1995. Geologia e Petrologia do Arquipélago de Fernando de Noronha. DGM/DNPM, Rio de Janeiro, Monografia, 13: 181.

Buikin, A.I., Korochantseva, E.V., Hopp, J., Trieloff, M., Kogarko, L.M. 2010. ${ }^{40} \mathrm{Ar}-{ }^{39} \mathrm{Ar}$ dating of volcanic rocks from Fernando de Noronha hot spot. Geochimica et Cosmochimica Acta, 72-12: A119.

Cordani U.G. 1970. Idade do vulcanismo no Oceano Atlântico Sul. Boletim do Instituto de Geociências e Astronômia da Universidade de São Paulo, 1: 9-75.

Gerlach, D.C., Stormer Jr., J.C., Mueller, P.A. 1987. Isotopic geochemistry of Fernando de Noronha. Earth and Planetary Science Letters, 85-1: 129-144.

Motoki, A., Motoki, K.F., Melo, D.P. Submarine morphology characterization of the Vitória-Trindade Chain and the adjacent areas, State of Espírito Santo, Brazil, based on the predicted bathymetry of the TOPO version 14.1. Revista Brasileira de Geomorfologia. (in press)

O'Connor, J.M., Roex, A.P. 1992. South Atlantic hot spotplume systems: 1. Distribution of volcanism in time and space. Earth and Planetary Science Letters, 113: 343-364.

Rivalenti, G., Zanetti, A., Girardi, V.A.V., Mazzucchelli, M., Tassinari, C.C.G., Bertotto, G.W. 2007. The effect of the Fernando de Noronha plume on the mantle lithosphere in north-eastern Brazil. Lithos, 94-1: 111-131.

Silveira, G., Stutzmann, E. 2002. Anisotropic tomography of the Atlantic Ocean. Physics of the Earth and Planetary Interiors, 132-4: 237-248.

Skolotnev, S.G., Peyve, A., Truko, N.N. 2010. New data on the structure of the Vitoria-Trindade seamount chain (western Brazil basin, South Atlantic). Doklady Earth Sciences, 431-2: 435-440.

Smith, W.H., Sandwell, D.T. 1997. Global sea floor topography from satellite altimetry and ship depth soundings. Science Magazine, 277-5334: 1957-1962. 